\title{
AS AÇÕES REGRESSIVAS PREVIDENCIÁRIAS DE TRÂNSITO: UMA QUESTÃO ECONÔMICO-SOCIAL, PREVIDENCIÁRIA E DE RESPONSABILIDADE CIVIL
}

Sebastião Aésio Marinho Cézar ${ }^{217}$

Recebido em: 21/08/2016

Aprovado em: 09/09/2016

\begin{abstract}
RESUMO
O presente artigo apresenta uma análise sobre os elementos que compõem as Ações Regressivas Previdenciárias de Trânsito, movidas pela Previdência Social, cuja titularidade compete ao Instituto Nacional do Seguro Social (INSS) e que representa, na atualidade, um dos assuntos mais polêmicos aos olhos do Direito Previdenciário brasileiro. Diante dos aspectos econômico-sociais, os elevados números de acidentes de trânsito envolvendo os segurados da Previdência Social acarretaram cerca de $\mathrm{R} \$ 410$ milhões com pagamento de benefício do tipo auxílio-doença, como também, $\mathrm{R} \$ 4$ bilhões com pagamento da aposentadoria por invalidez e R \$3,2 bilhões com pagamento da pensão por morte. A conduta humana (negligência e imprudência) apresentase como a principal causadora desses acidentes e quando comprovada é alvo da Ação Regressiva Previdenciária de Trânsito, por parte da Procuradoria-Geral Federal do INSS. O INSS procura demonstrar a existência dos requisitos da responsabilidade civil (ação ou conduta humana - dano ou prejuízo - nexo causal) ao demandar suas ações regressivas contra o motorista infrator.
\end{abstract}

Palavra-chave: Direito Previdenciário. Ações Regressivas Previdenciárias de Trânsito. Previdência Social.

\section{INTRODUÇÃO}

Com grande repercussão no país, principalmente, "aos olhos do Direito brasileiro", este tipo de ação regressiva não está completamente assentado no ordenamento jurídico do país, especialmente, por envolver questão previdenciária. No entanto, o assunto tem grande importância social, econômica e jurídica.

\footnotetext{
${ }^{217}$ Especialista em Direito Previdenciário pela Faculdade Damásio de Jesus (FDJ). Bacharel em Ciências Atuariais pela Universidade Federal do Rio Grande do Norte (UFRN). Professor de Legislação Previdenciária e de Introdução a Ciências Atuariais da Faculdade do Seridó (FAS). Endereço eletrônico: aesionat @ yahoo.com.br.
} 
O artigo, inicialmente, traz uma abordagem econômico-social dos números de acidentes de trânsito no Brasil, que é alarmante, para não dizer assustador. Todos os anos, milhares de acidentes interrompem drasticamente a trajetória dos jovens brasileiros e suas consequências são sentidas também pelos cofres da Previdência Social. Esta despende cerca de R \$ 12 bilhões por ano para cobrir as situações de riscos geradas aos seus segurados vitimados em decorrência dos acidentes de trânsito.

Em vista disso, a Previdência Social, representada pelo Instituto Nacional do Seguro Social - INSS, por intermédio de suas procuradorias, tem adotado postura mais proativa, exercendo o direito de regresso contra o causador do acidente de trânsito (motorista infrator) que negligenciar as normas de trânsito e causar incapacidade ou morte aos seus segurados.

De tal modo, a questão que se firma sobre o assunto consiste em debater se tais ações regressivas são possíveis dentro do nosso ordenamento jurídico e se representam ou não uma afronta a nossa Constituição Federal e, não diferentemente, ao Direito Previdenciário, uma vez que, essas medidas de ressarcimento constituem uma nova forma de responsabilizar as pessoas físicas (motoristas infratores) em face dos acidentes de trânsito por eles cometidos contra o segurado da Previdência Social e que, consequentemente, gere pagamento de benefícios previdenciários.

\section{OS ASPECTOS ECONÔMICO-SOCIAIS ENVOLVENDO AS AÇÕES REGRESSIVAS PREVIDENCIÁRIAS DE TRÂNSITO}

Partindo do princípio de que o Direito deve coadunar com a realidade social e a referida matéria traz em pauta um grave problema social com o qual o país vem se deparando durante décadas - as mortes no trânsito e os custos previdenciários a ele associado -, e que o Brasil é considerado um dos países que mais ocorre óbitos relacionados a esse tipo de acidente, consequentemente, um dos países com o trânsito mais perigoso do mundo. Assim sendo, é importante que se busque alternativas para reduzir esses números, e, com isso, possibilitar a Previdência Social recuperação dos valores despendidos precocemente, em decorrência das mortes dos seus segurados por esse tipo de acidente.

Infelizmente, os acidentes de trânsito, estão incorporados ao dia-a-dia das pessoas, trazendo graves problemas econômico-sociais e até mesmo previdenciários. Logo, esses acidentes trazem para a sociedade sérias consequências danosas, tais como incapacidades temporárias ou permanentes e até mesmo a morte de milhares de pessoas todos os anos. No 
entanto, quando esses acidentes abarcam segurados da Previdência Social geram inconvenientes (custos) que se materializam mediante coberturas (benefícios previdenciários), sejam eles: auxílio-doença, aposentadorias ou pensão por morte.

De acordo com os dados extraídos do sistema DATASUS, do Ministério da Saúde, desde o ano de 1979 até 2015, o número de acidentes de trânsito com vítimas fatais no país vem aumentando praticamente todos os anos e durante esse período foram contabilizadas aproximadamente 1,2 milhão de pessoas mortas, ou seja, são mais de 33 mil pessoas mortas em média por ano no trânsito brasileiro. Quando comparados por década, esses óbitos representam um aumento de aproximadamente $25,16 \%$ em relação à década de (80 a 90), de 14,78\% em relação à década de $\left(90\right.$ a 2000) e de $38,1 \%$ em relação à década atual ${ }^{218}$.

Adiante, o Gráfico 1 refere-se ao comportamento desses dados através de uma série temporal, no período de 1979 a 2015, do número de mortes por acidente de trânsito no Brasil.

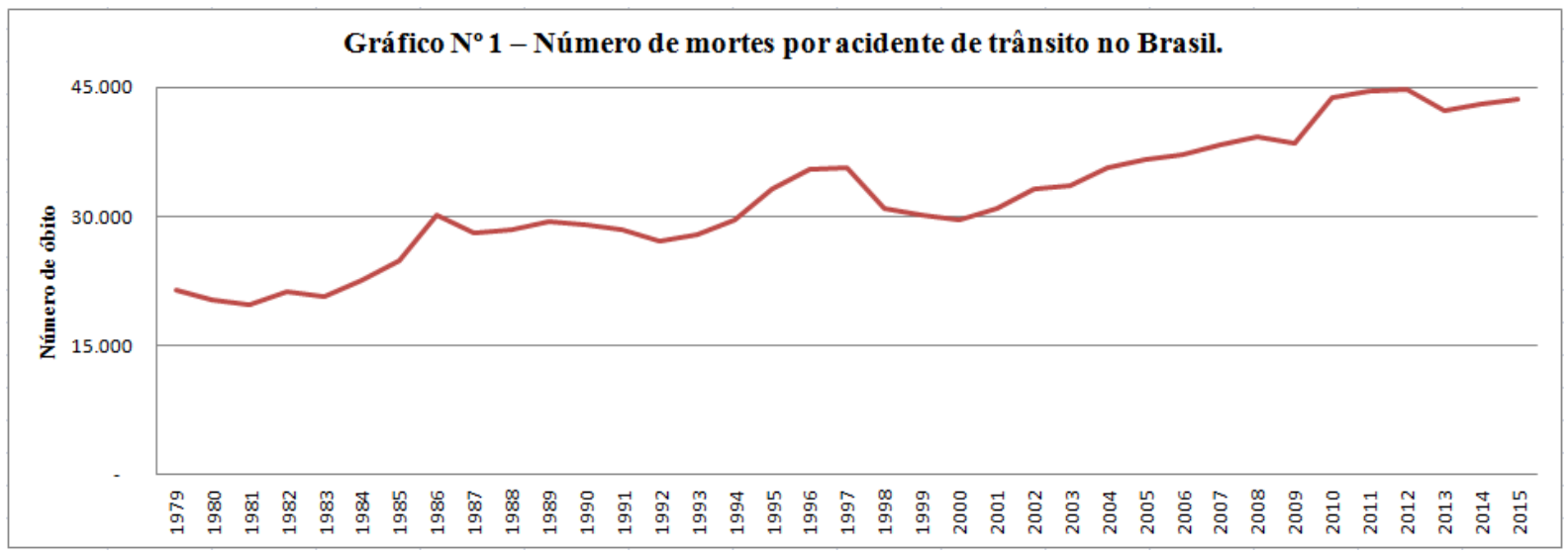

Fonte de dados básicos: Ministério da Saúde, sistema DATASUS (junho, 2016).

Destaca-se negativamente para o aumento no número de óbitos ao passar das décadas, mesmo com as mudanças inseridas pelo Código de Trânsito Brasileiro (CTB), como por exemplo, melhoria da segurança dos veículos com inclusão de air bag e freios ABS, incremento da fiscalização eletrônica de velocidade e utilização de bafômetros nas fiscalizações. Também merece registro da informação extraída da Confederação Nacional de Municípios Mapeamento das Mortes por Acidentes de Trânsito no Brasil (2009), grande parte dos óbitos por acidente de trânsito está entre a faixa etária dos 20 aos $39 \operatorname{anos}^{219}$, ou seja, quando as pessoas

\footnotetext{
${ }^{218}$ Os valores da década atual estão contabilizados parcialmente (2010 a 2015) por isso, apresentaram o percentual mais alto em relação às demais décadas. Extraído do Ministério da Saúde. Sistema DATASUS. Acesso em: 10 de junho de 2016.

${ }^{219}$ Extraído da Confederação Nacional de Municípios: Mapeamento das Mortes por Acidentes de Trânsito no Brasil. Acesso em 22 de julho de 2016.
} 
estão em idade economicamente ativa - em plenas condições para exercer atividade econômica, qualificando-se para o mercado profissional, etc.

Além disso, é importantíssimo para o país que esse catastrófico número de óbitos apresente redução a curto e médio prazo, tendo em vista que daqui algumas décadas, por volta do ano de 2025, o país começará a adentrar no fenômeno conhecido por bônus demográfico 220 e esse fenômeno se configurará como um facilitador para as reformas do país, principalmente a previdenciária ${ }^{221}$, já que esta coorte (faixa etária) de jovens estarão largamente superando a de dependentes (crianças e idosos).

Ademais, outro número vem chamando atenção da Previdência Social. São os números de pessoas com invalidez permanente decorrente dos acidentes de trânsito no país. O Gráfico 2, apresenta essa evolução indesejável e preocupante.

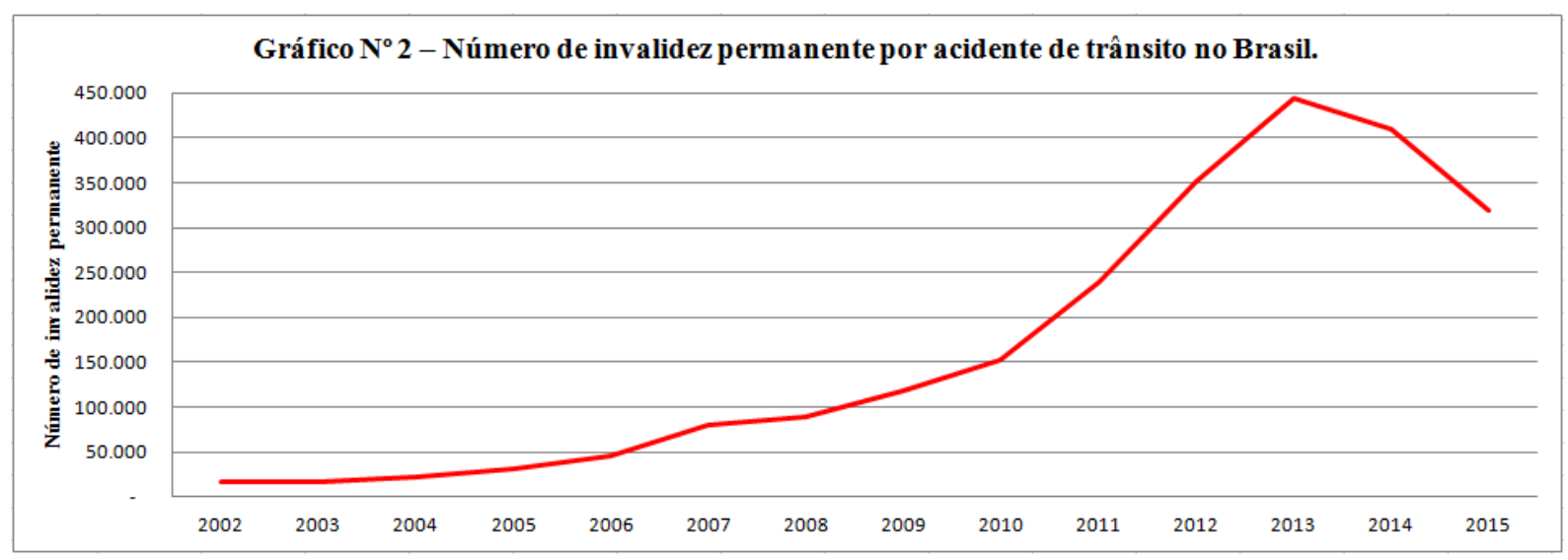

Fonte de dados básicos: Boletim Estatístico. Seguradora Líder - DPVAT (junho, 2016).

Durante esse período observa-se que mais de 1,6 milhão de pessoas ficaram incapacitadas permanentemente e que esses números se multiplicam por 5 (cinco) a cada cinco anos, ou seja, cresce numa projeção aritmética assustadora, durante o período de 2002 a 2013 e apresenta uma redução logo em seguida após esse período. No entanto, o quadro ainda é inquietante para o país e a Previdência Social, atenta a isso, teme ter de arcar com os custos de uma geração de jovens aposentados por invalidez.

Atualmente, cerca de 3 milhões de beneficiários recebem a aposentadoria por invalidez da Previdência Social. Outro dado alarmante e que chama a atenção do INSS é que a grande maioria desses segurados acidentados só contribuiu para a Previdência Social, em média, por

\footnotetext{
${ }^{220}$ Trata-se do período no qual a população economicamente ativa supera largamente a de dependentes, composta por idosos e crianças.

${ }^{221}$ Extraído da Revista Veja: Estudo do IBGE mostra "bônus demográfico" do país. Acesso em 21 de julho de 2016.
} 
cinco anos, mas que vão receber aposentadoria por invalidez pelo resto da vida ${ }^{222}$. Deste modo, percebe-se que a situação é realmente assustadora até porque a cada ano que se passa a expectativa de vida da população brasileira também tende aumentar, e arcar com esse custo (pagamento de benefício) quando se arrecada por pouco tempo e se paga por longos períodos é financeiramente insustentável.

2.1 Os custos dos acidentes de trânsito nas contas previdenciárias

Algumas peculiaridades em relação aos acidentes de trânsito são pouco discutidas na literatura científica e principalmente quando relacionada ao campo do Direito Previdenciário. Entre elas, o impacto econômico-financeiro que representa para o setor previdenciário com os pagamentos dos benefícios, especialmente, com as aposentadorias por invalidez e as pensões por morte.

A consequência financeira deste cenário acarretou para Previdência Social brasileira uma despesa anual por volta de $\mathrm{R} \$ 7,8$ bilhões no ano de 2011 e aumentou consideravelmente no ano de 2012, chegando à quantia dos $\mathrm{R} \$ 12$ bilhões com pagamento desses benefícios ${ }^{223}$. Destaca-se que no ano de 2013, do total das aposentadorias por invalidez permanente, $18 \%$ (dezoito por cento) foi concedida em decorrência de acidente de trânsito e gerou um custo previdenciário de aproximadamente $\mathrm{R} \$ 4$ bilhões $^{224}$. Ressalta-se que esse é um dos benefícios que mais ocasiona despesa para Previdência Social, já que a maioria das vítimas envolvidas são pessoas jovens e que, consequentemente, receberão tal benefício por um período de longa duração.

Ademais, outro elevado custo previdenciário está associado aos benefícios concedidos em decorrência das pensões por morte dos segurados do Regime Geral de Previdência Social RGPS por implicação desses acidentes de trânsito. De acordo com o Conselho Nacional de Previdência Social - CNPS, no ano de 2013, essas despesas chegaram à casa dos R \$ 3,2 bilhões, sem contar com as contribuições previdenciárias que a Previdência Social deixou e/ou deixa de receber motivada pela invalidez ou morte desses segurados, que de forma precoce cessou de contribuir para os cofres da Previdência. Além disso, a autarquia previdenciária gasta cerca de

\footnotetext{
${ }^{222}$ Extraído da Revista Folha de São Paulo: Invalidez por acidente de trânsito dispara. Acesso em 03 de novembro de 2015.

${ }^{223}$ Retirado da Revista Valor Econômico: Gastos da Previdência com acidentes de trânsito crescem $54 \%$ em dois anos. Acesso em: 02 de novembro de 2015.

${ }^{224}$ Extraído do Conselho Nacional de Previdência Social. Os números das mortes e invalidez no trânsito. Acesso em: 02 de novembro de 2015.
} 
$\mathrm{R} \$ 410$ milhões por ano com pagamento do benefício auxílio-doença para aproximadamente 120 mil segurados vítimas de acidentes de trânsito ${ }^{225}$.

Complementando esse cenário, os estudos da própria Previdência Social, apontam números muito preocupantes, já que em média 43 segurados por dia, não mais retornam ao trabalho devido à invalidez ou morte. De tal modo, paralelamente a esses números e valores exorbitantes é que o INSS procura, pouco a pouco, recuperar esses gastos decorrentes do binômio (motorista infrator causador de acidente de trânsito versus segurado da previdência social acidentado) mediante a proposição da ação regressiva em face desses condutores.

\section{AÇÕES REGRESSIVAS PREVIDENCIÁRIAS DE TRÂNSITO}

É natural que várias pessoas se manifestem a favor e outras contra as ações regressivas previdenciária de trânsito. Não é difícil entender o porquê. Primeiramente, porque não é justo que motoristas irresponsáveis tirem todos os dias centenas de vidas humanas e a sociedade arque com os prejuízos decorrentes desse tipo de comportamento. Em seguida, porque há os que defendem que não existe aplicabilidade ou fundamentação jurídica para esse tipo de ação. No entanto, quando se trata de tema previdenciário, não há como dividir a sociedade entre os que são "a favor" e os que são "contra", entre "interessados" e "não interessados" na matéria, pois ela interessa a todos.

\subsection{Direito de regresso}

O direito de regresso ou ação de regresso, de modo geral, constitui-se como instrumento jurídico posto à disposição daquele que ressarciu vítima de dano ocasionado por outrem e tem por propósito recuperar os gastos ocasionados a determinado indivíduo. Nesse sentido, destacase que o direito de regresso é existente no ordenamento jurídico brasileiro desde o antigo Código Civil, o qual trazia no seu artigo 1.524, o seguinte enunciado: "Art. 1.524. O que ressarcir o dano causado por outrem, se este não for descendente seu, pode reaver, daquele por quem pagou, o que houver pago".

Prontamente, o vigente Código Civil, mantém tal preceito e apresenta o direito de regresso, da seguinte forma: “Art. 934. Aquele que ressarcir o dano causado por outrem pode

\footnotetext{
225 Informação extraída do Ministério da Previdência Social. Publicação: 2012, ano II, no 2. Acesso em: 05 de novembro de 2015 .
} 
reaver o que houver pago daquele por quem pagou, salvo se o causador do dano for descendente seu, absoluta ou relativamente incapaz”. Dessa forma, a lei dá ao indivíduo, sendo ele pessoa física ou pessoa jurídica, o direito de, regressivamente, receber do verdadeiro responsável àquilo que teve de desembolsar em determinado momento.

A exemplo das palavras de Sílvio Venosa:

O terceiro que suporta indenização pode voltar-se contra o causador do dano para receber o que pagou. Busca-se restabelecer o equilíbrio patrimonial. Sabemos que na prática nem sempre esse ressarcimento é possível, mormente por ausência de patrimônio ou condições financeiras do ofensor. Trata-se, porém, de direito inafastável do que indenizou. (VENOSA, 2010, p. 117).

Além disso, outras normas de direito público também se referem à ação regressiva como forma de reconhecimento do direito de regresso em evidente analogia aos institutos do direito privado. Nesse sentido, a Procuradora Federal Maria Auxiliadora Castro e Camargo (2014) diz que: "não deve causar nenhum espanto o fato de que o direito público busque por meio do princípio da responsabilidade civil os fundamentos para que o Estado exerça seu direito regressivo contra quem causar dano ao patrimônio público".

E, é isso, que o Instituto Nacional do Seguro Social - INSS, através de sua procuradoria, está buscando nas suas ações regressivas previdenciárias. Logo, tal instrumento judicial exerceu e continua exercendo uma alternativa para obrigar o causador do dano a cumprir com suas obrigações com o ente lesado.

\subsection{Fontes do Direito Previdenciário nas ações regressivas}

As fontes do Direito são de grande importância para as ações regressivas previdenciárias, pois, através delas, é que se identificam quais são as origens do referido fenômeno jurídico (civil ou previdenciário) e como se deu o surgimento desse fenômeno. Destaca-se que o ordenamento jurídico brasileiro não permite que tenhamos normas que sejam incompatíveis entre si. Logo, o Direito não pode ser visto como um conjunto de ramos isolados. Consequentemente, qualquer fonte do Direito, no seu sentido formal, decorre de uma estrutura de poder, a qual traz a necessidade de garantia de cumprimento de determinada norma imposta à sociedade.

Castro e Lazzari trazem isso:

Fonte do Direito é todo fato social (fonte material). Contudo, deve-se estudar quais os fatos sociais geradores de normas jurídicas no campo do Direito Previdenciário, ou 
seja, de onde se originam os princípios e regras aplicáveis a este ramo do Direito (CASTRO e LAZZARI, 2012, p. 88).

Além disso, destaca-se que o primeiro ramo com o qual deverá existir ampla relação é com o Direito Constitucional, dado a fixação de diversos princípios e normas no texto constitucional. Já com o Direito Civil, a relação com Direito Previdenciário deverá se dá a partir da conceituação da responsabilidade civil.

3.3 Os pressupostos a serem observados nas ações regressivas previdenciárias de trânsito

Tendo por base o que dispõe a Cartilha de Atuação nas Ações Regressivas Previdenciárias da Advocacia Geral da União - AGU (2014), as ações regressivas previdenciárias de trânsito pressupõem a concorrência dos seguintes pressupostos:

a) acidente de trânsito que vitime segurado da Previdência Social.

Nesse caso, destaca-se que somente será possível a viabilização da ação regressiva previdenciária de trânsito quando ocorrer um evento que vitime um segurado da Previdência Social.

b) da despesa previdenciária.

De acordo com os termos do art. $3^{\circ}$ da Portaria Conjunta PGF/PFE-INSS n ${ }^{\circ}$ 06/2013, "consideram-se despesas previdenciárias ressarcíveis as relativas ao pagamento, pelo INSS, de pensão por morte e de benefícios por incapacidade, bem como aquelas decorrentes do programa de reabilitação profissional".

Todavia, destaca-se que não caberá o ressarcimento ao Instituto, nos casos em que o segurado for vítima de acidente de trânsito e já se encontrar em gozo do benefício de aposentadoria à época do ocorrido, a qual se origine na conversão desse benefício em pensão por morte, tendo em vista, não existir neste caso nenhum adicional de despesa aos cofres da autarquia.

c) da culpa do causador do acidente, consubstanciado na afronta dos dispositivos do Código de Trânsito Brasileiro (CTB).

Nesse sentido, o acidente deve resultar de uma conduta ilícita por parte do condutor do veículo, como por exemplo, dirigir após ingerir bebida alcoólica ou acima da velocidade permitida para via, conforme artigo 291, § $1^{\circ}$, I e III, da Lei $\mathrm{n}^{\circ}$ 9.503/1997. Deste modo, o entendimento da Procuradora-Geral do INSS é que quando o condutor do veículo dirigir sob 
influência de álcool, em zigue-zague, acima da velocidade permitida e sob consumo de drogas, o acidente deixa de fazer parte do risco natural ${ }^{226}$.

3.4 Objetivos das ações regressivas previdenciárias de trânsito

As ações regressivas previdenciárias de trânsito possuem objetivos claros no sentido de compensar a Previdência Social dos gastos com seus segurados vítimas de acidentes de trânsito, em decorrência de ato ilícito causado por motoristas infratores. De tal modo, os objetivos dessas ações têm por essência o caráter de recuperação dos valores desembolsados pelo INSS, em decorrência dos gastos com seus segurados acidentados e vitimados, por outrem, quando abarcados no acidente de trânsito. Logo, através desta medida, é que a autarquia pretende efetuar o ressarcimento das despesas gastas com o pagamento de benefícios por incapacidade ou morte de segurados, decorrentes dos acidentes ocorridos em descumprimento das normas de trânsito, por parte do motorista infrator.

Essa recuperação é almejada pelo INSS a fim de resguardar a sua integridade econômico-financeira e com isso tentar reaver a saída antecipada dos recursos públicos, em decorrência de um ato ilícito, causado por motoristas infratores contra os seus segurados. $\mathrm{Na}$ outra ponta, percebe-se o caráter preventivo-pedagógico da medida (ação regressiva) quando voltada à prevenção de cometimento de futuros acidentes automobilísticos, partindo do princípio que o melhor investimento é a ação preventiva conectada a uma melhor conduta às regras de trânsito e da defesa da integridade física do ser humano.

\subsection{Repercussões na área jurídica}

O ajuizamento das ações regressivas previdenciárias de trânsito ocasionou certa discussão no campo jurídico brasileiro, na qual há correntes que entendem que o ajuizamento dessas ações contra pessoa física não tem fundamento legal e que contraria à própria definição legislativa de ação regressiva previdenciária encontrada no art. 120 da Lei no 8.213/91 ${ }^{227}$; outros

\footnotetext{
226 INSS estuda casos de acidentes de trânsito para ressarcimento. Disponível em: <http://g1.globo.com/brasil/noticia/2011/11/inss-estuda-casos-de-acidentes-de-transito-pararessarcimento.html >. Acesso em 02 de setembro de 2015.

${ }^{227}$ Theodoro Vicente Agostinho. Revista Consultor Jurídico (novembro/2011). Disponível em: <http://consultorjuridico.jusbrasil.com.br/noticias/2911675/inss-entra-com-acao-regressiva-contra-motorista-que-causaacidente>. Acesso em: 02 de agosto de 2016.
} 
especialistas também entendem que falta base legal para esse tipo de ação ser inserida, ${ }^{228}$ já que trata especificamente de negligência quanto às normas-padrão de segurança e higiene do trabalho indicadas para a proteção individual e coletiva; e que de certa forma essas ações ferem o princípio da isonomia ${ }^{229}$.

No entanto, percebe-se que dentro do Direito Previdenciário brasileiro existem dois dispositivos legais que dão respaldo às ações regressivas previdenciárias e que no caso específico são: os arts. 120 e 121 da Lei no 8.213/91. Só que, no primeiro (art. 120) envolve caso de acidente do trabalho, causado pela negligência do empregador (pessoa jurídica), enquanto, no segundo (art. 121) trata do acidente de trabalho, porém não excluindo a responsabilidade civil da empresa ou de outrem (pessoas jurídicas ou pessoas físicas), em consonância com os termos dos arts. 186, 927 e 934 do Código Civil brasileiro, tendo em vista que esse tipo de responsabilidade não permanece afastada.

Sem contar que a autarquia também pode se utilizar do disposto do artigo $4^{\circ}$ da Lei de Introdução ao Código Civil Brasileiro, o qual traz: "Art. 4. Quando a lei for omissa, o juiz decidirá o caso de acordo com a analogia, os costumes e os princípios gerais de direito". A exemplo das palavras de Zeno Veloso:

\begin{abstract}
A lei pode ser omissa. Por mais sábio e previdente que seja o legislador não consegue regular todas as situações que surgirão no meio social. A vida é dinâmica, farta, ágil, criativa; a cada instante surgem fatos incalculáveis, inimagináveis. As lacunas na lei são inevitáveis. Daí, o art. 126 do Código de Processo Civil: "O juiz não se exime de sentenciar ou despachar alegando lacuna ou obscuridade na lei. No julgamento da lide caber-lhe-á aplicar as normas legais; não as havendo, recorrerá à analogia, aos costumes e aos princípios gerais do direito". (VELOSO, 2010, p. XLII)
\end{abstract}

Também é plausível que o INSS tente reaver os valores despendidos precocemente junto ao causador do dano previdenciário, através da referida ação regressiva, tendo por base a responsabilidade indireta, na qual não representa derrogação ao princípio da personalidade da culpa, até porque o responsável é legalmente considerado em culpa, pelo menos em razão da imprudência ou negligência expressa. Portanto, existindo o direito de ressarcimento fundamentado nos institutos do Direito Civil, mais precisamente na responsabilidade civil por ato ilícito. Sem falar aqui, do princípio da supremacia do interesse público!!

\footnotetext{
${ }^{228}$ Marcel Cordeiro. Revista Em Foco (dezembro/2011). Disponível em: $<$ http://www.editorajc.com.br/2011/12/em-foco-inss-utiliza-acoes-regressivas-para-reaver-despesas-decorrentesde-acidentes-de-transito/>. 02 de setembro de 2015.

${ }^{229}$ Marcelise Azevedo. G1 Globo Notícia (novembro/2011). Disponível em: <http://g1.globo.com/brasil/noticia/2011/11/inss-estuda-casos-de-acidentes-de-transito-pararessarcimento.html >. 02 de setembro de 2015.
} 
Além disso, outra forma de não ferir o princípio da isonomia, é não se basear em relação à igualdade formal do referido principio, ou seja, o que está disposto "friamente" no texto da norma, mas sim, em relação à igualdade material, real, efetiva e situada, constante também no coevo princípio - naquela que efetivamente deve ser buscada por meio de realização de tal intento. Assim, a concretização do princípio da igualdade depende do critério-medida objeto de diferenciação e de um fim a ser alcançado. E é justamente o que Humberto Ávila ensina:

\begin{abstract}
O princípio da igualdade, ele próprio, nada diz quanto aos bens ou aos fins de que se serve a igualdade para diferenciar ou igualar as pessoas. As pessoas ou situações são iguais de desiguais em função de um critério diferenciador. Duas pessoas são formalmente iguais ou diferentes em razão da idade, do sexo ou da capacidade econômica. Essa diferenciação somente adquire relevo material na medida em que se lhe agrega uma finalidade, de tal sorte que as pessoas passam a ser iguais ou diferentes de acordo com um mesmo critério, dependendo da finalidade a que ele serve. (ÁVILA, 2007, p. 150)
\end{abstract}

3.6 O dano observado

O dano vem desde o Direito Romano e no Direito Brasileiro, toda vez que alguém sofrer uma diminuição no seu patrimônio, contra sua vontade estará experimentando um prejuízo material, ou seja, sofrendo um dano. Azevedo (1998, p. 238) explica o significado desse instituto: “A palavra dano tem extensão ilimitada de sentido, representando o resultado de qualquer espécie de lesão (moral, religiosa, econômica, política etc.), entretanto, no prisma jurídico, o dano circunscreve-se a detrimência econômica ou moral".

Por sua vez, Diniz (1999, p. 55) corrobora trazendo outra definição: “O dano é um dos pressupostos da responsabilidade civil, contratual ou extracontratual, visto que não poderá haver ação de indenização sem a existência de um prejuízo e sendo imprescindível a prova real e concreta dessa lesão". Desta forma, observa-se que para existir o pagamento da indenização pleiteada pelo indivíduo é necessário comprovar a efetiva ocorrência do dano patrimonial.

Já Cavalieri Filho (2000, p.70) explica que "o dano é, sem dúvida, o grande vilão da responsabilidade civil. Não havendo que se falar em indenização, nem em ressarcimento, se não houvesse o dano". Logo, o dano ou prejuízo é uma lesão a um interesse jurídico tutelado, causado por ação ou omissão do sujeito infrator.

Além disso, Gagliano e Pamplona (2011, p. 80) lembram que a reparação do dano, mesmo proveniente de um ilícito civil, não envolve somente os interesses individuais, mas os interesses coletivos, até porque vivemos em sociedade e a violação do patrimônio do semelhante repercute, também, na esfera coletiva. 
Assim, baseado nesses entendimentos o próprio INSS pode se valer ao adentrar com as ações regressivas previdenciárias de trânsito, tendo em vista que, com a saída "precoce" de monetários derivado dos pagamentos de benefícios previdenciários (decorrentes dos acidentes de trânsito) poderá de certa forma afetar o seu equilíbrio financeiro à medida que esses benefícios forem pagos.

\subsubsection{Os requisitos do dano a indenizar}

Em regra, todos os danos devem ser ressarcíveis, sendo a reparação como produto da teoria da responsabilidade civil, uma sanção imposta ao responsável pelo prejuízo em favor do prejudicado. Assim, quando o condutor de veículo automotor, em decorrência de algum ato ilícito praticado ao conduzir o veículo, causar acidente que acarrete na invalidez ou morte precoce do segurado da Previdência Social, pode-se considerar que o INSS também é prejudicado, já que precocemente terá que desembolsar os pagamentos de benefícios previdenciários ao seu segurado ou ao dependente deste.

A bem ver e principalmente pelo que já foi abordado, o INSS e a sociedade não podem arcar com esses custos, tendo em vista que, se o motorista infrator não tivesse cometido o ato ilícito, não haveria a necessidade de concessão do benefício e sobretudo porque a Previdência Social não possui a finalidade de abarcar quaisquer contingências provenientes de ilegalidades. Assim, seguindo a ideia de Gagliano e Pamplona (2011) para que o dano possa ser efetivamente reparável é necessária à reunião dos seguintes requisitos:

i) A violação de um interesse jurídico patrimonial de uma pessoa física ou jurídica;

Nesse caso observa-se que todo dano deverá pressupor a agressão a um bem tutelado, de natureza material ou não, pertencente a um sujeito de direito.

ii) A certeza do dano;

Aqui a certeza refere-se à sua existência, ou seja, o dano certo e efetivo é indenizável. Portanto, não há como obrigar ninguém a compensar a vítima por um dano abstrato ou hipotético, havendo a necessidade de comprovação (aspecto processual).

iii) A subsistência do dano;

Logo, o dano deverá subsistir no momento de sua exigibilidade em prejuízo, caso contrário, perde-se o interesse da responsabilidade civil. 
Como observa Gagliano e Pamplona (2011, p. 46) "a formulação de um conceito de responsabilidade, no campo jurídico, não se restringe ao Direito Civil, aplicando-se, respeitadas as devidas peculiaridades, a todos os outros campos do Direito, como na esfera penal, administrativa, tributária e previdenciária”.

De tal modo, há o princípio da responsabilidade civil, o qual está diretamente relacionado à noção de não prejudicar outro, ou seja, parte do sentido da Máxima Romana Neminem Laedere (a ninguém é dado causar prejuízo a outrem). No entanto, quando isso não ocorre, abre precedente para a aplicação de medidas que obriguem alguém a reparar o dano causado a outrem em razão de sua ação ou omissão. Assim, o anseio de obrigar o agente, causador do dano, a repará-lo inspira-se no mais elementar sentimento de justiça.

Ademais, seguindo também o entendimento de Bittar (1994), a tendência é de não deixar a vítima de atos ilícitos sem o devido ressarcimento, de forma a restaurar seu equilíbrio moral e patrimonial, conforme se pode observar:

O lesionamento a elementos integrantes da esfera jurídica alheia acarreta ao agente a necessidade de reparação dos danos provocados. É a responsabilidade civil, ou obrigação de indenizar, que compele o causador a arcar com as consequências advindas da ação violadora, ressarcindo os prejuízos de ordem patrimonial ou moral, decorrente de fato ilícito próprio, ou de outrem a ele relacionado. (BITTAR, 1994, p. $561)$.

Assim, percebe-se que a responsabilidade civil não se resume apenas na obrigação de quem causou o dano de repará-lo, de regressar a situação do lesado ao status quo, mas também e, principalmente, em garantir uma relação jurídica equilibrada e ética. Deste modo, pode-se observar a existência de duas situações envolvendo a responsabilidade civil do causador do dano em relação às ações regressivas previdenciárias de trânsito:

$1^{\circ}$ ) Quando traz a responsabilidade subjetiva ${ }^{230}$, tendo em vista que estão presentes na relação, de forma direta e em primeiro plano, o agente causador do dano (motorista infrator) e o agente que sofreu o dano (segurado da Previdência Social). Porém, a vítima (segurado) na maioria das vezes só obterá a reparação do dano se provar a culpa do agente causador do dano, o que nem sempre é possível na sociedade moderna. Quando isso ocorre, há a possibilidade de ignorar-se a comprovação da culpa, bastando existir o nexo causal entre a pessoa e o dano para então surgir à responsabilidade de indenizar.

${ }^{230}$ É causada por conduta culposa lato sensu, que envolve a culpa stricto sensu (quando o agente causador do dano praticar o ato com negligencia ou imprudência) e o dolo (é a vontade conscientemente dirigida à produção do resultado ilícito). 
$2^{\circ}$ ) Quando apresenta a figura da responsabilidade objetiva ${ }^{231}$, tendo em vista o efeito regressivo presente na relação jurídica, entre o agente causador do dano (motorista infrator) e a entidade previdenciária (INSS), em decorrência da chamada teoria do risco, adotada pela lei brasileira. Mas, há quem defenda que deve ser aplicada.

Do mesmo modo, essa relação possibilita a reparação do dano aos cofres públicos, no caso específico, o da Previdência Social, por implicação de atitude contrária ao Direito - não diligente ao cumprimento das normas de trânsito pelo motorista infrator, que vitime um segurado da Previdência Social.

Logo, para corroborar com essa ideia, as palavras de Carlos Alberto Pereira de Castro e João Batista Lazzari (2008), em relação ao caráter objetivo das ações regressivas:

O Estado, por meio do ente público responsável pelas prestações previdenciárias, resguarda a subsistência do segurado e seus dependentes, mas tem o direito de exigir do verdadeiro culpado pelo dano que este arque com os ônus das prestações aplicando-se a noção de responsabilidade objetiva, conforme a teoria do risco social para o Estado (CASTRO e LAZZARI, 2008, p. 562).

\section{OS ASPECTOS DE ORDEM PROCESSUAL DAS AÇÕES REGRESSIVAS PREVIDENCIÁRIAS DE TRÂNSITO}

O INSS nas ações regressivas previdenciária de trânsito busca reaver os gastos decorrentes de prestações sociais geradas precocemente por condutores de veículos automotores, que vitimem segurados da Previdência Social. Compreende-se que a principal fundamentação das ações regressivas previdenciárias de trânsito é de evitar o prejuízo da integridade dos recursos públicos, já que o erário público e a sociedade que o custeia não devem assumir o prejuízo decorrente de um ato ilícito causado por condutor de veículo automobilístico, que por motivo de negligência ou imprudência, vitime segurado da Previdência Social.

Nesse caso, o que se busca é que, de certa forma, a sociedade não absorva o risco proveniente de um ato ilícito, mesmo admitindo que todos contribuem para um fundo comum que cobrirá os riscos sociais. Desta forma, o que se procura através dessas ações regressivas é tentar minimizar que toda sociedade e a autarquia saíam prejudicados, tendo em vista que, quando o governo adota uma política pública de custeio, os gastos com esses acidentes afetam

\footnotetext{
${ }^{231}$ É quando desconsidera a culpa como elemento indispensável na relação e não se indaga se o ato é culpável, mas se há relação de nexo de causalidade.
} 
não apenas esses envolvidos na relação específica, mas toda a massa de segurados da Previdência Social.

De ante mão, os fundamentos desse tipo de ação regressiva compreende a demonstração do descumprimento do dever de cuidado objetivo e, de certa forma, a própria intenção em ofender o bem jurídico protegido, manifestado pela desobediência e/ou infringência às normas ao qual o condutor está submetido, quando na direção do veículo. Deste modo, as fundamentações baseiam-se no afrontamento aos bens jurídicos tutelados e ainda no descumprimento de normas a segurança do trânsito, proteção às pessoas, à saúde e integridade física da população.

\subsection{Previsão Legal}

Observa-se que o argumento defendido pelo INSS para mover as ações regressivas previdenciárias de trânsito em relação à pessoa física é formulado basicamente acerca da responsabilidade civil, e que no caso específico, consiste na tentativa de buscar o ressarcimento de seus cofres, quando os seus segurados são vítimas de motoristas causadores de acidentes de trânsito. Essa previsão legal encontra-se embasamento na esfera infraconstitucional do nosso ordenamento jurídico, de acordo com os artigos 186, 927 e 934 do Código Civil brasileiro, que assim se referem cada um dos referidos artigos:

“Art. 186. Aquele que, por ação ou omissão voluntária, negligência ou imprudência, violar direito e causar dano a outrem, ainda que exclusivamente moral, comete ato ilícito". No entanto, percebe-se que este ato ilícito é praticado em desacordo com a ordem jurídica, mas não é desejado pelo agente. Contudo, esclarece Diniz (2010, p. 157) que:

\footnotetext{
É imprescindível para configuração desse ato os seguintes elementos: a) o fato lesivo voluntário, causado pelo agente, por ação ou omissão voluntária, em decorrência da negligência ou imprudência; b) a ocorrência de um dano patrimonial e/ou moral ${ }^{232}$; c) o nexo de causalidade entre o dano e o comportamento do agente causador.
}

Assim, por meio da existência desses elementos (conduta humana, nexo de causalidade, dano e culpa) é que a autarquia procura mover suas ações de caráter regressivo, comprovando a existência do nexo entre o ato ilícito do réu e o evento que gerou o pagamento de benefícios previdenciários ao segurado, do qual se requer o ressarcimento. Logo, observa-se a exigência desses elementos como requisitos essenciais para argumentação da ação:

\footnotetext{
${ }^{232}$ De acordo com a Súmula $n^{\circ} 37$ do Supremo Tribunal de Justiça serão cumuláveis as indenizações por dano material e moral decorrente do mesmo fato.
} 
[...] Como se sabe, para que surja o dever de indenizar basta a comprovação de três requisitos fundamentais: a) o dano suportado pela vítima; b) o ato culposo pelo agente; c) o nexo causal entre o dano e a conduta culposa. $O$ autor de uma ação de indenização por ato ilícito tem, pois, de provar os três requisitos acima, pois são eles, em seu conjunto, o fato constitutivo que se pretende exercitar em face do réu. No caso em tela, a tríplice concorrência do prejuízo encontra-se documentada nos autos. [...] (TRF 1 ${ }^{\mathrm{a}}$ REGIÃO. APELAÇÃO CÍVEL No 1997.01.00.039881-5/MG - Quarta Turma. REL. DES. FED. SELENE MARIA DE ALMEIDA. Brasília, 14/05/1999).

“Art. 927. Aquele que, por ato ilícito (arts. 186 e 187), causar dano a outrem, fica obrigado a repará-lo". Isso significa que, uma vez verificada a existência de culpa, gera-se o dever de indenizar por parte do agente causador, mas há que estar presente o nexo causal entre sua conduta e o dano produzido.

Nesse caso a doutrina firma-se no dever de reparar o dano, já que passa pelo caráter de ressarcimento do prejuízo. Assim, explica Regina Beatriz Tavares da Silva (2010):

\footnotetext{
Muito embora a doutrina não seja uniforme na conceituação da responsabilidade civil, é unânime na afirmação de que este instituto jurídico firma-se no dever de reparar o dano, explicando-o por meio de seu resultado, já que a ideia de reparação tem maior amplitude do que a de ato ilícito, por conter hipótese de ressarcimento de prejuízo sem que se cogite da ilicitude da ação. (SILVA, 2010, p. 786 e 787)
}

“Art. 934. Aquele que ressarcir o dano causado por outrem pode reaver o que houver pago daquele por quem pagou, salvo se o causador do dano for descendente seu, absoluta ou relativamente incapaz". Trata-se da responsabilidade indireta, na qual vigora o princípio do direito de regresso daquele que suporta seus efeitos contra aquele que tiver praticado o ato ilícito. Nesse ponto é evidente que é isso que a autarquia vem buscando quando promove suas ações regressivas.

\subsection{Princípio envolvido}

No Direito brasileiro princípios são normas imediatamente finalísticas, nas quais se estabelecem um fim a ser atingido. No entanto, o fim não precisa, necessariamente, representar um ponto final qualquer, mas apenas um conteúdo desejado. Assim, princípio é uma suposição que se coloca na base da ciência, informando-a e orientando-a sempre que se precisar. A exemplo das palavras de Humberto Ávila:

Os princípios são normas imediatamente finalísticas, primariamente prospectivas e com pretensão de complementariedade e de parcialidade, para cuja aplicação se demanda uma avaliação da correlação entre o estado de coisas a ser promovido e os efeitos decorrentes da conduta havida como necessária à sua promoção. (ÁVILA, 2007, p. 78 e 79) 
Prontamente, o princípio mais evidente quanto se trata da ação regressiva previdenciária de trânsito é o princípio da responsabilidade civil, já que trata da reparação de prejuízo suportado. Cavalieri Filho (2010) traz o que exprime esse instituto:

A responsabilidade civil é um dever jurídico sucessivo que surge para recompor o
dano decorrente da violação de um dever jurídico originário. O responsável é a pessoa
que deve ressarcir o prejuízo decorrente da violação de um precedente dever jurídico.
Daí toda conduta humana que, violando o dever jurídico originário, causa prejuízo a
outrem é fonte geradora de responsabilidade civil. (CAVALIERI FILHO, 2010, p. 2)

Além disso, percebe-se uma correlação entre esse princípio e o tipo de ação regressiva proposta pelo INSS, em relação aos requisitos (elementos) da responsabilidade civil:

a) ação ou conduta humana;

Existência de violação a direito - em alguns casos a Previdência Social se depara precocemente com o fim do recebimento da contribuição previdenciária, em relação ao seu segurado, decorrente do falecimento ou invalidez deste, motivado, por exemplo, pelo acidente automobilístico causado por atos ilícitos de terceiros, quando comumente deveria continuar recebendo até que esse segurado alcançasse o tempo final de contribuição. Logo, percebe-se que esse direito de certa forma foi violado abruptamente por terceiros.

b) dano ou prejuízo;

No caso específico é o prejuízo material suportado pela autarquia.

c) nexo causal;

É o elo entre a ação e o dano material sofrido pela autarquia.

Nesse sentido, destaca-se que a responsabilidade civil avança conforme se desenvolve a civilização, havendo necessidade de constante adaptação deste instituto às novas necessidades sociais. Assim, lembra Silva (2010, p. 788), que "as leis sobre essa matéria devem ter caráter genérico e os tribunais cabem delas extrair os preceitos para aplicá-los ao caso concreto".

Portanto, o dever de reparar surge, em regra de atos ilícitos, diante dos quais são necessários itens como a demonstração da culpa do lesante, e, em caráter excepcional, por forma de disposição legal expressa, tendo em vista o agente colocar em ação forças que são fontes de perigo e de potenciais danos para outrem. Mas, sem esquecer que a responsabilidade não se resume apenas na forma de reparação do dano ao lesado e sim em garantir uma relação jurídica equilibrada e ética.

5.3 Legitimidade nas ações regressivas previdenciárias de trânsito 
No que concerne à capacidade processual, a legitimidade ativa das ações regressivas previdenciárias e não diferentemente, as de trânsito, por disposição do art. 121 da Lei 8.213/91 e dos arts. 186, 927 e 934 do Código Civil é da Previdência Social. Logo, a legitimidade para propor esse tipo de ação é representada por dois pólos:

a) No pólo ativo da ação regressiva previdenciária: encontrasse o INSS, por se tratar de uma autarquia pública federal, deverá ser representada judicialmente por suas Procuradorias Federais distribuídas pelo país;

b) No pólo passivo da demanda da ação regressiva previdenciária: figurasse o responsável pelo dano causado ao INSS. Nesse sentido, ocorrendo o descumprimento às normas que regulamentam o código de trânsito ou o cometimento de ilícitos penais que resultarem em lesão corporal, morte ou perturbação funcional estará suscetível a possibilitar o ajuizamento de ações regressivas previdenciárias por parte do Instituto, contra o causador do dano.

Entretanto, a concessão de benefícios gerados pelo descumprimento da norma acima referenciada, determinada por um ato ilícito, viola as premissas da Previdência Social e, consequentemente configura dano ao Regime Geral da Previdência Social - RGPS. Sendo o INSS gestor desse patrimônio, o mesmo deve buscar o ressarcimento das despesas previdenciárias realizadas e por realizar, conservando o seu direito de regresso, baseado na responsabilidade civil, contra aqueles que deram causa.

Destaca-se para os pedidos que são veiculados através dessas ações, já que abrangem prestações vencidas e vincendas em decorrência do caráter continuado das prestações sociais. Dessa forma, as prestações vencidas deverão ser pagas após o julgamento definitivo da ação de ressarcimento previdenciário, com os devidos acréscimos (juros legais e correção monetária). Já no caso das prestações vincendas serão restituídas de forma periódica pelo condutor do veículo infrator que causou o acidente ao segurado da Previdência Social.

\subsection{A Jurisprudência}

Por sua vez, a jurisprudência, como fonte informadora do Direito, tem se pautado de maneira decisiva para a viabilidade da reparação civil do dano sofrido dentro da concepção previdenciária ora discorrida. Apesar de que até novembro de 2013, apenas três ações regressivas previdenciárias sobre os acidentes de trânsito, envolvendo segurado da Previdência 
Social foram movidas no país e tendo sentença favorável ao INSS ${ }^{233}$. Contudo, destaca-se que essas ações são de regiões distintas do país (Sudeste, Centro-Oeste e Nordeste).

Outro objetivo com o intuito dessas ações, é que a jurisprudência pouco a pouco se torne comum nos tribunais do país, e com isso os causadores desse tipo de dano previdenciário possam de certa forma se "acostumarem" a pagarem as indenizações quando causarem lesão ou morte de segurado do INSS, conforme se pode observar nas ações abaixo:

SENTENÇA: TRF/1 ${ }^{a}$ REGIÃO. (TRF $1^{a}$ REGIÃO. APELAÇÃO CÍVEL No 1997.01.00.039881-5/MG - Quarta Turma. REL. DES. FED. SELENE MARIA DE ALMEIDA. Brasília, 14/05/1999).

SENTENÇA: JFRN/1 ${ }^{\mathrm{a}}$ VARA. (JFRN. AÇÃO ORDINÁRIA. PROCESSO No 0004849-39.2012.4.05.8400. $1^{\text {a }}$ VARA FEDERAL. JUIZ FEDERAL: MAGNUS AUGUSTO COSTA DELGADO. Natal/RN, 29/01/2013).

SENTENÇA: JFRJ/3 $3^{\mathrm{a}}$ VARA. (JFRJ. AÇÃO ORDINÁRIA. PROCESSO No 0001846-78.2013.4.02.5115. 3 $3^{\text {a }}$ VARA FEDERAL. JUIZ FEDERAL: FÁBIO TENENBLAT. São Gonçalo/RJ, 16/12/2013).

Outro ponto a se destacar nesse tipo de ação regressiva e que deve ser estendida para as demais (futuras) ações embasadas nos artigos 186, 927 e 932 do Código Civil é a existência da apresentação dos pressupostos da responsabilidade civil, como também, referenciar à responsabilidade subjetiva do causador do dano.

\subsection{Competência e Ajuizamento}

A norma administrativa da Procuradoria-Geral Federal do INSS é bastante relevante ao estabelecer os procedimentos administrativos e as análises técnicas, referentes à competência e ao ajuizamento das ações regressivas previdenciárias. Entre as suas disposições, destacam-se:

a) Sob a competência:

De acordo com art. 109, inciso I, $\S 1^{\text {o }}$, da Constituição Federal e do art. 16 da Portaria Conjunta PGF/PFE-INSS nº 6, de 18 de janeiro de 2013, será de compete à Justiça Federal da subseção do foro do domicílio do réu processar e julgar a ação regressiva previdenciária.

b) Sob o ajuizamento:

A ação regressiva previdenciária será proposta quando estiverem presentes os elementos suficientes de prova da ocorrência do ato ilícito, da culpa, do nexo causal e da realização de despesas previdenciárias. Assim, o órgão de execução da PGF do local do ajuizamento será responsável pela elaboração da petição inicial e a distribuição da ação regressiva previdenciária

\footnotetext{
${ }^{233}$ Previdência Social. Ações regressivas colocam freio à impunidade no trânsito. Publicação ano IV, $\mathrm{n}^{\circ}$ 8, JaneiroAbril de 2014. Disponível em: <http://www.previdencia.gov.br/wpcontent/uploads/2014/04/Previd\%C3\%AAncia-Social.pdf > . Acesso em: 05 de setembro de 2015.
} 
para o Procurador Federal, no qual deverá providenciar o cadastramento do processo e observar os seguintes critérios:

Relevância: Social; Classe da ação: Ação Regressiva; Autor: INSS; Réu(s): Demandado(s); Tema: Cobrança e Recuperação de Créditos; Subtema: Ressarcimento ao Erário e Objeto do Pedido: INSS Ressarcimento ao Erário decorrente de ação regressiva previdenciária.

Portanto, observa-se que o ajuizamento dependerá da análise do caso pela ProcuradoriaGeral Federal, a quem cabe o levantamento dos elementos probatórios que justifique o ajuizamento e o respeito ao princípio da igualdade em seu sentido material.

Além disso, é imprescindível no sentido de que a petição inicial deverá detalhar rigorosamente o ato ilícito, a culpabilidade, o nexo causal, e o dano, este caracterizado pelas despesas previdenciárias ocorridas e por ocorrer, ou seja, o pedido do ressarcimento deverá ser integral (prestações vencidas e prestações vincendas). Dessa forma, não poderá ser ajuizada a ação regressiva previdenciária sem tais fundamentos, e, caso isso ocorra, sua conclusão deverá ser pelo não ajuizamento.

\section{CONSIDERAÇÕES FINAIS}

O alarmante número de pessoas (segurados) mortas e acometidas por incapacidades decorrentes dos acidentes de trânsito precisa de medidas, não só por parte da sociedade, mas da camada política e dos órgãos públicos envolvidos diretamente e indiretamente no problema. Consta-se que o comportamento humano, a conduta imprudente e negligente do condutor do veículo é considerado o principal responsável pelos acidentes de trânsito.

Seus reflexos quando relacionados às lesões e as mortes, envolvendo segurados da Previdência Social acarretam, em regra, em milhares de pagamentos de benefícios previdenciários, como o auxílio-doença, aposentadoria por invalidez e pensão por morte. Ademais, os números de acidentes dessa natureza deixam à mostra o grave problema a ser discutido, não só pela sociedade, mais também pelo nosso ordenamento jurídico.

Conclui que o efeito das ações regressivas previdenciárias de trânsito, na esfera jurídica brasileira e na sociedade, tem-se:

A possibilidade jurídica do direito de regresso com base nos arts. 121 da Lei $\mathrm{n}^{\circ}$ 8.213/91 e nos artigos números 186, 927 e 934 do Código Civil; 
Que as fontes do Direito Previdenciário trazem uma segurança para sucesso das referidas ações, tendo em vista à relação existente com a responsabilidade civil nas referidas ações;

$>$ Que as ações regressivas possibilitam a Previdência Social e a sociedade de forma geral, a não arcarem com os gastos decorrentes do descumprimento das normas de trânsito, por parte da negligência do condutor do veículo, que por hora causar lesão ao segurado da previdência e com isso acarretar pagamento de benefícios previdenciários;

O princípio mais evidente quanto se trata dessas ações regressivas é o princípio da responsabilidade civil, tendo em vista tratar da reparação do prejuízo suportado;

As Procuradorias Federais do INSS devem ater-se as exigências dos requisitos da responsabilidade civil (ação ou conduta humana - dano ou prejuízo - nexo causal), ou seja, aos elementos probatórios que justifique o ajuizamento das referidas ações regressivas;

As iniciativas dessas ações visam coibir tais práticas através de um conceito punitivo pedagógico e tende a se consolidar no ordenamento jurídico brasileiro.

Por fim, longe de ser pacífico o assunto, é reconhecido que o tema ainda deve ser bem estudado e aprofundado, e que seu enfrentamento requer mais publicações e divulgações sobre a matéria no atual cenário brasileiro.

\section{REFERÊNCIAS BIBLIOGRÁFICAS}

AÇÃO REGRESSIVA. INSS quer de volta o que gastou com acidente de trânsito. Disponível em: <http://www.conjur.com.br/2011-nov-03/inss-entra-acao-regressivamotorista-causa-acidente>. Acesso em: 15 de julho de 2016.

ADVOCACIA GERAL DA UNIÃO - AGU. Cartilha de Atuação nas Ações Regressivas Acidentárias. Brasília, 2014.

. AGU e INSS protocolam em Brasília $1^{\text {a }}$ Ação Regressiva contra causador de acidente de trânsito que gerou indenização da Previdência Social. Disponível em:<http://www.agu.gov.br/page/content/detail/id_conteudo/169794>. Acesso em: 15 de julho de 2016. 
AGOSTINHO, Theodoro Vicente; SALVADOR, Sérgio Henrique. A total antijuridicidade das novas ações regressivas do INSS. Disponível em: <http://www.trabalhistaeprevidenciaria.com.br/artigoseteses/artigo_novasacoesregressivasdoi nss.pdf $>$. Acesso em 02 de setembro de 2015.

ÁVILA, Humberto. Teoria dos princípios: da definição à aplicação dos princípios jurídicos. $7^{\mathrm{a}}$ ed. São Paulo: Malheiros, 2007.

BRANDÃO, Cláudio. Acidente do trabalho e responsabilidade civil do empregador. $3^{\mathrm{a}}$ ed. São Paulo: LTr, 2009.

BRASIL. Lei no. 8.213/1991. Planos de Benefícios da Previdência Social. Disponível em: <http://www.planalto.gov.br/ccivil_03/leis/18213cons.htm>. Acesso em: 30 de julho de 2016.

Disponível em:

Ministério da Previdência Social. Publicação: 2012, ano II, no 2. <http://www.previdencia.gov.br/arquivos/office/3_120425115428-524.pdf>. Acesso em: 05 de novembro de 2015.

Ministério da Previdência Social. Publicação ano IV, nº 8, Janeiro-Abril de 2014. Ações regressivas colocam freio à impunidade no trânsito. Disponível em:<http://www.previdencia.gov.br/wp-content/uploads/2014/04/Previd\%C3\%AAnciaSocial.pdf $>$. Acesso em: 05 de setembro de 2015.

Ministério da Saúde: Sistema DATASUS. Disponível em: $\langle$ http://www2.datasus.gov.br/DATASUS/index.php?area=0205>. Acesso em: 19 de julho de 2016.

PGF/PFE-INSS. Portaria Conjunta Procuradoria Geral Federal/Procuradoria Federal Especializada Junto ao INSS nº 6 de 18.01.2013. Disponível em: <http://www.normaslegais.com.br/legislacao/portaria-conj-pgf-pfe-inss-6-2013.htm>. Acesso em 02 de agosto de 2016.

PLS. Projeto de Lei $\mathbf{n}^{\mathbf{0}} \mathbf{2 6 4 / 2 0 1 2}$ do Senado Federal. Disponível em: <http://www.senado.gov.br/atividade/materia/detalhes.asp?p_cod_mate=106565>. Acesso em 20 de outubro de 2015.

CAMARGO, Maria Auxiliadora Castro e. A ação regressiva acidentária do INSS, sua natureza jurídica e os tribunais. Disponível em: < http://www.agu.gov.br/page/download/index/id/12017896>. Acesso em: 13 de julho de 2016. 
CASTRO, Carlos Alberto Pereira de; LAZZARI, João Batista. Manual de Direito Previdenciário. $9^{\mathrm{a}}$ ed. Florianópolis: Conceito, 2008.

Manual de Direito Previdenciário. 14ª ed. Florianópolis: Conceito, 2012.

CAVALIERI FILHO, Sérgio. Programa de responsabilidade civil. $9^{a}$ ed. São Paulo: Atlas, 2010.

CNM. CONFEDERAÇÃO NACIONAL DE MUNICÍPIOS. Mapeamento das Mortes por Acidentes de Trânsito no $\quad$ Brasil. $\quad$ Disponível em: $\langle$ http://www.pmrv.sc.gov.br/publicacoesETrabalhosArquivo.do?cdPublicacao=2490>.

Acesso em 22 de julho de 2016.

CNPS. Conselho Nacional de Previdência Social. Os números das mortes e invalidez no trânsito. Disponível em: 〈http://www.fsindical.org.br/new/noticia.php?id_conteudo=29617> . Acesso em: 02 de novembro de 2015.

DENATRAN. Conceitos adotados. Disponível em:<http://www.denatran.gov.br/publicacoes/Instrucao\%20Basica\%20de\%20Estatistica\%20d e\%20Transito/1-3.htm>. Acesso em 05 de agosto de 2016.

DINIZ, Maria Helena. Curso de Direito Civil brasileiro. Responsabilidade Civil. $19^{\text {a }}$ ed. São Paulo: Saraiva, 2011.

EDITORAJC. Em Foco: INSS utiliza ações regressivas para reaver despesas decorrentes de acidentes de trânsito. Disponível em: $<\mathrm{http}: / / \mathrm{www}$.editorajc.com.br/2011/12/em-foco-inssutiliza-acoes-regressivas-para-reaver-despesas-decorrentes-de-acidentes-de-transito/>. Acesso em 16 de julho de 2016.

GAGLIANO, Pablo Stolze; PAMPLONA FILHO, Rodolfo. Novo Curso de Direito Civil. Responsabilidade Civil. 9a ed. São Paulo: Saraiva, 2011.

HADDAD, Sônia Rodrigues; MORITA, Patrícia Alessandra e CAVALCANTE, Fátima Gonçalves. Sequelas invisíveis dos acidentes de trânsito. Disponível em: <http://www.ipea.gov.br>. Acesso em 03 de outubro de 2015.

IBRAHIM, Fábio Zambitte. Curso de Direito Previdenciário. $18^{\mathrm{a}}$ ed. Rio de Janeiro: Impetus, 2013. 
KERTZMAN, Ivan. Curso Prático de Direito Previdenciário. $11^{\mathrm{a}}$ ed. Salvador: JusPodivm, 2014.

NEGRÃO, Theotônio; GOUVÊA, José Roberto Ferreira. Código Civil e legislação civil em vigor. $22^{a}$ ed. São Paulo: Saraiva, 2003.

REVISTA CONSULTOR JURÍDICO. INSS entra com ação regressiva contra motorista que causa acidente. Disponível em: $<$ http://consultorjuridico.jusbrasil.com.br/noticias/2911675/inss-entra-com-acao-regressiva-contra-motoristaque-causa-acidente>. Acesso em: 02 de agosto de 2016.

REVISTA FOLHA DE SÃO PAULO. Invalidez por acidente de trânsito dispara. Disponível em: <http://www.apm.org.br/noticias-conteudo.aspx?id=7234>. Acesso em 03 de novembro de 2015 .

REVISTA VALOR ECONÔMICO. Gastos da Previdência com acidentes de trânsito crescem 54\% em dois anos. Disponível em: <http://csbbrasil.org.br/gastos-da-previdenciacom-acidentes-de-transito-crescem-54-em-dois-anos/>. Acesso em: 02 de novembro de 2015.

REVISTA VEJA. Estudo do IBGE mostra "bônus demográfico" do país. Disponível em: <http://veja.abril.com.br/noticia/economia/estudo-do-ibge-comprova-bonus-demograficodo-pais>. Acesso em 21 de julho de 2015.

SILVA, Regina Beatriz Tavares da; DINIZ, Maria Helena; VELOSO, Zeno. Código Civil Comentado. $7^{a}$ ed. São Paulo: Saraiva, 2010.

UOL. O INSS a os motoristas infratores. Disponível em:<http://ultimainstancia.uol.com.br/conteudo/colunas/53893/o+inss+e+os+motoristas+infra tores+.shtml>. Acesso em: 15 de julho de 2015.

VENOSA, Silvio. Curso de Direito Civil. 5ª ed. São Paulo: Saraiva, 2010.

NEW CIVIL PROCEDURE CODE. THE SLACKEN OF RES JUDICATA AND THE RESCISSION ACTION AGAINST THE NATIONAL TREASURY 
This article presents an analysis of the elements of the Shares Regressive Transit Social Security, powered by Social Security, whose ownership responsibility of the National Social Security Institute (INSS), which is, today, one of the most controversial issues in the eyes of right Brazilian Social Security. Faced with the economic and social aspects, the high numbers of traffic accidents involving insured Social Security resulted approximately $\mathrm{R} \$ 410$ million with payment of benefit sickness type, as well as $\mathrm{R} \$ 4$ billion with payment of invalidity pension and $\mathrm{R} \$ 3.2$ billion with payment of pension for death. Human behavior (negligence and recklessness) is presented as the main cause of these accidents and if proven is the target of Action Regressive Transit Social Security, by the Federal Attorney-General of the INSS. The INSS seeks to demonstrate the existence of the liability requirements (action or human conduct - damage or injury - causation) to demand their regressive actions against the offending driver.

Keywords: Social Security Law. Regressive actions Transit Social Security. Social Security. 